\title{
The Effect of Inoculation With Amycolatopsis Strains On Yield and Nutrient Content of Wheat (Triticum Aestivum L.) and Soil Microbiological Properties
}

Maira Kussainova ( $\square$ maira.kussainova@kaznau.kz)

Kazakh National Agrarian Research University https://orcid.org/0000-0002-9800-6093

Rıdvan Kızılkaya

Ondokuz Mayis University Faculty of Agriculture: Ondokuz Mayis Universitesi Ziraat Fakultesi

\section{Research Article}

Keywords: Amycolatopsis strains, inoculation, wheat straw, plant yield, microorganism.

Posted Date: September 3rd, 2021

DOI: https://doi.org/10.21203/rs.3.rs-814356/v1

License: (1) This work is licensed under a Creative Commons Attribution 4.0 International License.

Read Full License 


\section{Abstract}

In this study, the yield and nutrient content of wheat (Triticum aestivum L.) grown in greenhouse conditions and soil microbiological properties were investigated. Inoculating Amycolatopsis strains, including A.magusensis DSM $45510^{\top}$, A. orientalis DSM $40040^{\top}$, and A.azurea DSM $43854^{\top}$ was considered. The mixture of wheat straw (WS) was used to increase soil organic matter content by $5 \%$. It was determined that the grain and straw yield of wheat increased significantly $(P<0.001)$ in inoculation with Amycolatopsis strains in soils without WS. However, inoculation with Amycolatopsis strains in soil with WS significantly decreased grain and straw of wheat yield. Also, it was found that soil microbial biomass and soil basal respiration (SBR) increased in inoculation with Amycolatopsis strains in both soils with and without WS. While it was established that $\mathrm{C}_{\text {mic }}: \mathrm{C}_{\text {org }}$ ratio of the control group in the soil samples at the end of the harvest was 1.23, infusing with Amycolatopsis strains was observed to be around 2.95-3.31. Moreover, inoculation with Amycolatopsis strains in soils with WS varied between $0.32-0.40$. In the same way, it was determined the microbial metabolic quotient $\left(q \mathrm{CO}_{2}\right)$ was 2.58 in the control group. This meaning was between 5.67-5.82 in infusing with Amycolatopsis strains and 6.046.41 in inoculating with Amycolatopsis strains in soils mixed with ground wheat stalk. As a result, it suggested that the yield of wheat could be increased inoculation with A.magusensis, A.orientalis, and A.azurea, from Amycolatopsis strains, in soils with low soil organic matter content and soils that cannot be shown an increment in terms of organic matter content.

\section{Introduction}

Agricultural systems commonly put excess pressures on the soils, leading to environmental problems and the exhaustion of natural resources. In the long run, the rapid increase in the yield of production by adding chemical inputs replaces with the gradual declining trend. Eventually, farming systems that produce healthy foods would collapse. Production of healthy foods without using agricultural chemicals is compulsory for the sustainable use of natural resources. For the sustainability, some actions that need to be considered, including prevention of environmental pollution, maintaining agricultural sustainability, ensuring the sustainability of natural resources, reducing agricultural expenses, and using plant hormoneproducing and nitrogen-fixing microorganisms.

Many microorganisms, such as plant growth-promoting rhizobacteria (PGPR), can naturally promote plant growth. The usage of a biological fertilizer as a sustainable approach to increasing crop yield provides many benefits to the host plant after the infusing (Gouda et al., 2018; Backer et al., 2018). Apart from the species belonging to PGPR microorganism, using bacterial species including Azotobacter, Acetobacter, Azosprillum, Burkholderia, Pseudomonas, Bacillus, and Paenibacillus are reported by several researchers (Saubidet et al., 2002; Lucy et al., 2004). Bacteria that stimulate plant growth by controlling harmful microorganisms are called biopesticides (Banerjee et al., 2005). However, it is known that some PGPRs act as both biofertilizers and biopesticides to stimulate plant growth. For example, while Burkholderia cepacia species has biocontrol properties against Fusarium species, they also contribute to the development of corn with the formation of siderophores in iron-poor conditions (Bevivino et al., 1998). 
The effects of PGPRs on crop yield can vary according to the climate and ecological conditions of the grown plants and the region. Soil properties can also impact their performance. Many physicochemical properties such as texture, $\mathrm{pH}$, salinity, and nutrient content play an essential role in the PGPRs on yield (Hussain et al., 1999; Valarini et al., 2003). Increasing soil organic substance improves the efficiency of PGPRs by providing the carbon and energy source for PGPRs (Fageria, 2012).

So far, PGPRs are used for an antibiotical activity such as balhimycin, vancomycin, and rifamycin (Kumari et al., 2016), synthesis of vanillin (Fleige et al., 2016), and polycyclic aromatic hydrocarbons degradation capacities (Ortega-González et al., 2015). In this study, the possibility of using Amycolatopsis strains as PGPR was investigated. For this purpose, the effect of wheat (Triticum aestivum L.) grown in greenhouse conditions on yield, nutrient content, and soil microbiological properties were evaluated. Microbial inoculating was carried out with A.magusensis DSM 45510 ${ }^{\top}$, A.orientalis DSM $40040^{\top}$, and A. azurea DSM $43854^{\top}$, from Amycolatopsis strains. Besides, soils were mixed with and without ground wheat straw (WS) to consider the factor of organic substance input. The results of wheat yield and soil microbiological properties were studied in detail.

\section{Material And Methods}

\section{Soil and wheat straw}

Soil samples used in this study were taken from the most biologically active part of soil $(0-20 \mathrm{~cm})$. The soil was collected from arable agriculture field for a long time. The field is located on the Black Sea Region of Northern Turkey (latitude, $41^{\circ} 21^{\prime} \mathrm{N}$; longitude, $36^{\circ} 15^{\prime} \mathrm{W}$ ). The region has a semi-humid climate with temperatures ranging from $3.8^{\circ} \mathrm{C}$ in February to $27^{\circ} \mathrm{C}$ in August, with an annual mean temperature of $14.5^{\circ} \mathrm{C}$. The annual mean precipitation is $718 \mathrm{~mm}$. The field has no background in receiving pesticide and fertilizer treatments within the last six months before the soil sampling. The soil in the field was classified as Vertic Haplustoll, according to the FAO (2006). The soil sample was homogenized, dried, gently crumbled, and screened from $2 \mathrm{~mm}$ opening sieve to remove stones, gravels, and root material. Basic soil properties were analyzed according to the method proposed by Rowell (1996). The obtained results were measured to be as follows: $\mathrm{pH}(1: 1 \mathrm{w}: \mathrm{v}) 7.10$; total organic matter $1.73 \%$; conductivity (1:1 w:v) 0.94 $\mathrm{dSm}^{-1}$, lime $\left(\mathrm{CaCO}_{3}\right)$ content $11.74 \%$; total nitrogen (Kjeldahl $\mathrm{N}$ ) \%0.18; available P (Olsen-P) $23.52 \mathrm{mg}$ $\mathrm{kg}^{-1}$; exchangeable $\mathrm{K} 1.12 \mathrm{cmol} \mathrm{kg}^{-1}$; and exchangeable Ca: $23.08 \mathrm{cmol} \mathrm{kg}^{-1}$. The soil sample used in this study had a clay loam textural class, including $29.55 \%$ clay, $43.06 \%$ silt, and $27.39 \%$ sand.

In this research, wheat straw (WS) was obtained from the Experimental Field of Agricultural Faculty, Ondokuz Mayıs University, Samsun, Turkey. The WS, with no diseases or contaminating insects, was dried at $65^{\circ} \mathrm{C}$. Whole WS materials, including stalks and leaves, were chopped into $10 \mathrm{~cm}$ pieces, grounded, sieved from $0.50 \mathrm{~mm}$, and stored in polyethylene bags at $5^{\circ} \mathrm{C}$. The properties of WS were expressed on a dry basis and analyzed according to standard procedures given by Jones (2001). The WS 
had approximately $79 \%$ of oxidizable organic matter. The organic fraction of WS had $45.9 \% \mathrm{C}$ and $0.89 \%$ $\mathrm{N}$, while the inorganic fraction of WS had $2.60 \% \mathrm{P}, 5.01 \% \mathrm{~K}, 1.10 \% \mathrm{Ca}$, and $1.3 \% \mathrm{Mg}$ by weight.

\section{Bacterial culture and inoculant preparation}

Three Amycolatopsis strains (i.e., A.magusensis DSM 45510 ${ }^{\top}$, A.orientalis DSM $40040^{\mathrm{T}}$, and A.azurea DSM 43854 ${ }^{\top}$ ) were obtained from Soil Microbiology Laboratory in Ondokuz Mayis University, Samsun, Turkey. Amycolatopsis strains are known as an essential source of various bioactive compounds such as antibacterial, antifungal, and antiviral. Pure cultures of three Amycolatopsis strains used for inoculation were grown in SM2 medium at $28^{\circ} \mathrm{C}$ for seven days. To prepare selective medium SM2, the procedure given by Tan et al. (2006) was performed as follows: $67.0 \mathrm{~g}$ yeast nitrogen base and 100 mg casamino acids were added to a liter of distilled water, and the solution sterilized using $0.20 \mu \mathrm{m}$ cellulose filters prior to the addition of sterilized $\mathrm{K}_{2} \mathrm{HPO}_{4}(200 \mathrm{ml}, 10 \% \mathrm{w} / \mathrm{v})$. Thereafter, $100 \mathrm{ml}$ of basal medium was added to $900 \mathrm{ml}$ of sterilized molten agar $(1.5 \% \mathrm{w} / \mathrm{v})$ followed by filter-sterilized solutions of $\mathrm{D}(+)$ melezitose $(1 \%$ $\mathrm{w} / \mathrm{v}$ ) (final concentration $1 \% \mathrm{w} / \mathrm{v}), 50 \mu \mathrm{g}$ cycloheximide $\mathrm{ml}^{-1}, 4 \mu \mathrm{g}$ neomycin sulfate $\mathrm{ml}^{-1}$, and $50 \mu \mathrm{g}$ nystatin $\mathrm{ml}^{-1}$.

A single colony from each strain was transferred to a $50 \mathrm{~mL}$ flask, including $\mathrm{N}$ and agar free SM2 medium. The resulting medium was grown aerobically in flasks for 168 hours while on a rotating shaker (125 rpm) at $28^{\circ} \mathrm{C}$. Amycolatopsis strains grown liquid SM2 medium was then diluted with sterile distilled water, containing $0.025 \%$ Tween 20 to obtain a final concentration of $10^{9} \mathrm{CFU} \mathrm{ml}^{-1}$. Before sowing seeds into unsterilized soil, spring wheat (Triticum Aestivum L.) seeds were placed in bacterial suspensions of $10^{9} \mathrm{CFU} \mathrm{ml}^{-1}$ for 30 min under sterilized conditions.

\section{Greenhouse experiment}

A pot experiment was carried out in the greenhouse with the spring wheat (Triticum Aestivum L.) in order to investigate the effects of inoculation with Amycolatopsis strains. The experiment consisted of eight treatments with three replications, and the pots were distributed in a completely randomized design. The experiments consisted of three treatments of Amycolatopsis strains (A.Magusensis DSM 45510 ${ }^{\top}$, A.Orientalis DSM $40040^{\top}$, and A.Azurea DSM 43854 ${ }^{\top}$ ) and a control treatment without Amycolatopsis strains inoculation. Twenty-five seeds were sown to the soil in each $5 \mathrm{~L}$ pot. After the emergence of the first leaf, plants were thinned to fifteen per pot. The pots were daily irrigated to maintain soil moisture level at $60 \%$ of water holding capacity for 124 days after sowing. The greenhouse experiment was designed according to a complete randomized plot with three replicates. The 72 experiment pots were performed in accord with the eight treatments appended below: 


\begin{tabular}{l|ll|}
\hline (1) & Control (without WS, without Amycolatopsis inoculation) \\
$\qquad$\begin{tabular}{lll} 
(2) & With addition WS, without Amycolatopsis inoculation \\
(3) & Amycolatopsis magusensis DSM $45510^{\top}$ \\
(4) & Amycolatopsis magusensis DSM $45510^{\top}+50 \mathrm{~g} \mathrm{~kg}^{-1} \mathrm{WS}$ \\
(5) & Amycolatopsis orientalis DSM $40040^{\top}$ \\
(6) & Amycolatopsis orientalis DSM $40040^{\top}+50 \mathrm{~g} \mathrm{~kg}^{-1} \mathrm{WS}$ \\
(7) & Amycolatopsis azurea DSM $43854^{\top}$ \\
(8) & Amycolatopsis azurea DSM $43854^{\top}+50 \mathrm{~g} \mathrm{~kg}^{-1} \mathrm{WS}$ \\
\hline
\end{tabular} \\
Harvest and plant analyses
\end{tabular}

Studied plant parameters included grain yield, straw yield, and nutrient concentration in grain and straw at the end of the pots experiment in the greenhouse. The dry matter of the plant was determined after oven drying to constant mass at $65^{\circ} \mathrm{C}$. The dried samples were ground in a hammer mill to pass through a $0.5 \mathrm{~mm}$ mesh sieve. Then, the plant samples were analyzed to measure total $\mathrm{N}, \mathrm{P}, \mathrm{K}$, and $\mathrm{Ca}$. Whole pot was used for biomass determination at harvest. All parameters were measured according to the method suggested by Jones (2001).

\section{Soil microbiological analyses}

The soil samples taken from the pots were transferred to the laboratory on the same day and kept in the refrigerator at $4^{\circ} \mathrm{C}$. The soil microbiological analysis was carried out no longer than $72 \mathrm{~h}$ prior. All microbiological properties were analyzed for the soil samples in triplicate, and all values were reported as a mean of three replications expressed on an oven-dried sample basis at $105^{\circ} \mathrm{C}$ for $24 \mathrm{~h}$.

The soil samples were sieved through a $150 \mu \mathrm{m}$ mesh before determining the total organic carbon ( $\mathrm{C}_{\text {org }}$ ) by the wet oxidation method (Walkley-Black) with $\mathrm{K}_{2} \mathrm{Cr}_{2} \mathrm{O}_{7}$ (Rowell, 1996). Soil basal respiration (SBR), $\mathrm{CO}_{2}$ production at $22^{\circ} \mathrm{C}$ without the addition of glucose at field capacity, was measured according to the method given by Anderson (1982). Microbial biomass carbon $\left(\mathrm{C}_{\mathrm{mic}}\right)$ was determined by the substrateinduced respiration (SIR) method according to the method given by Anderson and Domsch (1978). The ratio of $\mathrm{C}_{\text {mic }} / \mathrm{C}_{\text {org }}$ was estimated as a percentage (\%). Specific respiration of the microbial biomass (the microbial metabolic quotient, $q \mathrm{CO}_{2}$ ) was calculated as the ratio of $\mathrm{BR}$ to $\mathrm{C}_{\text {mic }}$ by following formula $\left(\mathrm{BR} / \mathrm{C}_{\text {mic }}=q \mathrm{CO}_{2}, \mu \mathrm{CO}_{2}-\mathrm{C} \mathrm{mg}^{-1} \mathrm{C}_{\text {mic }} \mathrm{h}^{-1}\right)$.

\section{Statistical analysis}

All experimental data were analyzed for analysis of variance (ANOVA) using SPSS 11.0 statistical software (SPSS Inc.). ANOVA was carried out according to the completely randomized design, where 
significant $F$-values were obtained. The significance between the means was tested using the DUNCAN test at the level of $P<0.01$. All tables presented, including standard errors of the data and $F$-values. The asterisks, $* * *$, and $* \star *$ were used to indicate the significance level at $P<0.05,0.01$, and 0.001 , respectively.

\section{Results And Discussion}

\section{Wheat yield}

In order to determine the effects of grain and straw yield of wheat, inoculating Amycolatopsis strains alone and together with WS was performed. The obtained results are summarized in Table 1. According to the results, significant increases in wheat straw and grain yield after applying only $5 \%$ WS to the soil ( $P$ $<0.001$ ) were observed relative to the control. Regarding the control without any amendment, an increase of $24 \%$ in straw yield and $49 \%$ in grain yield were determined (Table 1 ). Similar to studies carried out by Brock et al. (2011) and Zhao et al. (2016), significant increases were noted in plant crop yield as a result of the application of organic compounds to the soil. Two main reasons could explain these increases in crop yield. First, the nutrient content of the soil increases after the amendment as plant nutrients are full of organic compounds in the structure, and thus, contributing to an increase in crop yield (Espe et al., 2015). Secondly, there is an increase in plant crop yield due to organic compounds applied to soils. It could improve soil properties such as aggregate stability, water retention capacity, and cation exchange capacity (Murphy, 2015).

It was determined that Amycolatopsis strains inoculated into the soil significantly increased grain and straw yield of the wheat compared to control (Table 1). The increase was mostly observed for the inoculation of $A$.azurea. In this case, grain yield and straw yield were increased by $274 \%$ and $74 \%$, respectively, compared to the control. The associated reasons for the increase in plant production in microbial inoculation to soils could be due to i) fixation of atmospheric $\mathrm{N}$ by microorganisms (Kızılkaya, 2009), ii) increase in the solubility of organic and inorganic $P$ in the soil by microorganisms (Ogut and $E r$, 2016), and iii) hormones that increase plant development such as auxins (Egamberdiyeva, 2005), cytokinins (Garcia de Salamone et al., 2001), gibberellins (Gutiérrez-Mañero et al., 2001) by microorganisms such as the production of microbial metabolites and hydrolytic enzymes, and vitamins (Ahmad et al., 2018). In addition to those, it could be due to creating a better plant growth environment by increasing the aggregation by microorganisms or indirect effects such as antibiotic production. There is no scientific evidence that Amycolatopsis strains would carry out $\mathrm{N}$ fixation, increases the solubility of organic and inorganic $\mathrm{P}$ in soil, or directly affect the yield of plant crops by synthesizing hormones such as gibberellins, auxin. However, Amycolatopsis strains could synthesize antibiotics such as balhimycin, vancomycin, rifamycin (Nigam et al., 2014; Xu et al., 2014; Frasch et al., 2015; Kumari et al., 2016), vanillin (Fleige and Steinbüchel, 2014; Fleige et al., 2016) and therefore, causing polycyclic aromatic hydrocarbons to degrade (Ortega-González et al., 2015). In this study, the fact that A.magusensis, A.orientalis, and A.azurea increased the grain and straw yield of the wheat, could be attributed to the antibiotic synthesis properties of Amycolatopsis strains. 
Table 1

The effects of inoculating Amycolatopsis strains alone and together with WS on grain and wheat yield

\begin{tabular}{|c|c|c|c|c|}
\hline \multirow[t]{2}{*}{ Treatments } & \multicolumn{2}{|l|}{ Weight (gr/pot) } & \multicolumn{2}{|l|}{ Change (\%) } \\
\hline & Straw & Grain & Straw & Grain \\
\hline Control & $10.26 \pm 0.32 \mathrm{~d}$ & $2.44 \pm 0.10 \mathbf{e}$ & - & -- \\
\hline WS $\left(50 \mathrm{~g} \mathrm{~kg}^{-1}\right)$ & $12.74 \pm 1.43 \mathrm{c}$ & $3.64 \pm 0.21 d$ & $24.20 \pm 13.91 \mathrm{~d}$ & $49.04 \pm 8.53 d$ \\
\hline A. magusensis & $15.53 \pm 0.56 b$ & $7.54 \pm 0.21 \mathbf{c}$ & $51.36 \pm 5.42$ c & $208.88 \pm 8.62 c$ \\
\hline A. orientalis & $16.16 \pm 0.61 b$ & $8.67 \pm 0.20 \mathbf{b}$ & $57.47 \pm 5.94 b$ & $255.46 \pm 8.20 \mathrm{~b}$ \\
\hline A. azurea & $17.92 \pm 1.01 \mathrm{a}$ & $9.14 \pm 0.15 \mathbf{a}$ & $74.63 \pm 9.84 \mathbf{a}$ & $274.45 \pm 5.97 \mathrm{a}$ \\
\hline A. magusensis $+50 \mathrm{~g} \mathrm{WS} \mathrm{kg}^{-1}$ & $2.15 \pm 0.16 \mathbf{e}$ & $1.21 \pm 0.03 \mathbf{f}$ & $-79.01 \pm 1.58 \mathbf{e}$ & $-50.55 \pm 1.25 \mathbf{e}$ \\
\hline 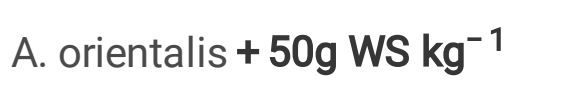 & $2.86 \pm 1.50 \mathbf{e}$ & $0.98 \pm 0.03 \mathbf{f}$ & $-72.12 \pm 1.57 \mathbf{e}$ & $-59.97 \pm 1.03 \mathbf{f}$ \\
\hline A. azurea $+\mathbf{5 0 g}$ WS $\mathbf{k g}^{-1}$ & $2.54 \pm 0.06 \mathbf{e}$ & $1.20 \pm 0.02 \mathbf{f}$ & $-75.21 \pm 0.54 \mathbf{e}$ & $-50.96 \pm 0.63 \mathbf{e}$ \\
\hline F-value & $172.346^{\star \star \star}$ & $1862.946^{\star \star \star}$ & 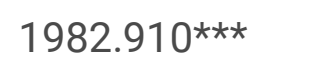 & $175.361^{\star \star \star}$ \\
\hline
\end{tabular}

As given in Table 1, Amycolatopsis strains applied to the soil together with WS decreased the grain and straw yield dramatically $(P<0.001)$. Compared to the control, the reduction in the grain yield by Amycolatopsis strains varied between $50-60 \%$. Moreover, the straw yield was found to be between $72-$ $79 \%$. The wheat yield increased when WS and Amycolatopsis strains alone were applied to the soil. It is interesting to note that wheat yields drop significantly after the application of these together. Amycolatopsis strains inoculated with WS affected more significantly by the soil microbiological properties. It was found that $\mathrm{C}_{\mathrm{mic}}$ and SBR were more available in pots with these combinations (Table 3). This may be due to heterotrophic Amycolatopsis strains, which supply the $\mathrm{C}$ from the organic $\mathrm{C}$ compound of WS. Thus, they were the dominant microflora in the environment. In this context, the growing population could synthesize more antibiotics, and this may result from the lack of positive effects of microflora on wheat yield by suppressing other microflora. Especially, bacteria populations such as nitrifier bacteria involved in $\mathrm{N}$ transformation might disappear from the environment due to the synthesized antibiotics. Eventually, this might prevent the formation of nutrients that can be taken as mineral $\mathrm{N}$, and plant yield may have decreased.

\section{Nutrient contents of wheat}

The application of Amycolatopsis strains alone and together with WS was studied to understand the effects of grain and straw of wheat within different scopes. The obtained results within the scope of $\mathrm{N}$ 
and $\mathrm{P}$ are given in Table 2. The corresponding results within the scope of $\mathrm{K}$ and $\mathrm{Ca}$ are presented in Table 3. It was found that the nutrient content of the wheat increased in general as a result of the application of WS and Amycolatopsis strains alone and together. It was observed that the application led to increases in the $\mathrm{N}$ and $\mathrm{P}$ content in the grain and straw of the wheat compared to the control. When WS applied with Amycolatopsis strains (Table 2), this application also increased the content of grain $\mathrm{K}$ and stem $\mathrm{Ca}$ content of the plant (Table 3). Jones et al. (1991) reported that the nutrient adequacy levels of the leaves of the wheat plant should be $1.75-3 \% \mathrm{~N}, 0.2-0.5 \% \mathrm{P}, 1.5-3 \% \mathrm{~K}$, and $0.2-1 \% \mathrm{Ca}$. According to these values, it was found that in the control application, the $\mathrm{N}$ content of the plant samples at harvest was insufficient. However, $\mathrm{P}, \mathrm{K}$, and Ca contents were found to be sufficient.

Similarly, Orhan et al. (2006), Çakmakçı et al. (2001), Kızılkaya (2008), Esitken et al. (2010) found that the product yield and nutrient content of the plant such as N, P, and K significantly increase with the inoculation of different microorganisms to the soil, in raspberry, sugar beet and barley, spring wheat, strawberry, respectively. In this study, the main reason why P, K, Ca contents of the plant in the control application without any fertilizer application are determined at a sufficient level is, without a doubt, due to the fact that the test soil contains sufficient levels of $P\left(23.52 \mathrm{mg} \mathrm{kg}^{-1}\right), \mathrm{K}\left(1.12 \mathrm{cmol}(+) \mathrm{kg}^{-1}\right)$ and $\mathrm{Ca}$ $\left(23.08 \mathrm{cmol}(+) \mathrm{kg}^{-1}\right)$ to meet the plant's need. It is thought that the $\mathrm{N}(0.18 \%)$, which was initially found in the soil at an average level, did not fully meet the requirements of the plant during the vegetation period. With microbial inoculations in the soil, increased nutrient content in the plant is related to promotes the mineral uptake of plants, and microorganisms promote mineral uptake with different mechanisms (Gouda et al., 2018; Backer et al., 2018). However, it may not be due to the normal ion uptake of mineral uptake by plants but due to volume increase of root system that is made of root amount, thickness, and length. Increased number of lateral roots by bacteria and widening of the root tips increases root surface area and it causes the plant to absorb more water and nutrients (Pinton et al., 2007). In inoculation with Amycolatopsis strains, including antibiotics secreted by the bacterial species, secretions do not only protect the plant root system against pathogenic organisms but also increases plant root development and eventually increases mineral intake by plants so that more nutrients may be absorbed by grain and straw of wheat. 
Table 2

The effects of inoculating Amycolatopsis strains alone and together with WS on N and P contents of wheat

\begin{tabular}{|c|c|c|c|c|}
\hline \multirow[t]{2}{*}{ Treatments } & \multicolumn{2}{|l|}{$\mathbf{N}(\%)$} & \multicolumn{2}{|l|}{$\mathrm{P}(\%)$} \\
\hline & Straw & Grain & Straw & Grain \\
\hline Control & $0.68 \pm 0.04 \mathbf{g}$ & $1.72 \pm 0.08 \mathbf{e}$ & $0.35 \pm 0.01 c$ & $0.46 \pm 0.01 b$ \\
\hline WS $\left(50 \mathrm{~g} \mathrm{~kg}^{-1}\right)$ & $0.82 \pm 0.03 f$ & $2.65 \pm 0.06 \mathrm{c}$ & $0.45 \pm 0.02$ b & $0.44 \pm 0.01 \mathrm{c}$ \\
\hline A. magusensis & $1.28 \pm 0.09 \mathbf{b}$ & $3.38 \pm 0.07 \mathbf{a}$ & $0.56 \pm 0.02 \mathbf{a}$ & $0.51 \pm 0.02 \mathrm{a}$ \\
\hline A. orientalis & $1.23 \pm 0.05$ bc & $3.19 \pm 0.06 \mathbf{b}$ & $0.54 \pm 0.01 \mathbf{a}$ & $0.52 \pm 0.01 \mathrm{a}$ \\
\hline A. azurea & $1.39 \pm 0.06 \mathbf{a}$ & $2.27 \pm 0.10 \mathbf{d}$ & $0.55 \pm 0.01 \mathbf{a}$ & $0.52 \pm 0.01 \mathrm{a}$ \\
\hline A. magusensis $+\mathbf{5 0} \mathrm{g} \mathrm{WS}_{\mathbf{~ k g}}{ }^{-1}$ & $1.00 \pm 0.06 \mathbf{e}$ & $2.25 \pm 0.10 \mathrm{~d}$ & $0.33 \pm 0.01 \mathbf{c}$ & $0.31 \pm 0.01 d$ \\
\hline A. orientalis $+50 \mathrm{~g} \mathrm{WS} \mathrm{kg}^{-1}$ & $1.08 \pm 0.03 \mathrm{de}$ & $2.37 \pm 0.14 \mathrm{~d}$ & $0.34 \pm 0.02 \mathrm{c}$ & $0.33 \pm 0.02 d$ \\
\hline A. azurea $+\mathbf{5 0} \mathbf{g ~ W S ~} \mathbf{k g}^{-1}$ & $1.16 \pm 0.07 \mathbf{c d}$ & $2.24 \pm 0.09 \mathrm{~d}$ & $0.34 \pm 0.01 \mathrm{c}$ & $0.34 \pm 0.02 d$ \\
\hline F-value & $59.463^{\star \star *}$ & $116.798^{\star \star \star}$ & $138.806^{\star \star \star}$ & $105.018 * \star \star$ \\
\hline
\end{tabular}


Table 3

The effects of inoculating Amycolatopsis strains alone and together with WS on K and Ca contents of wheat

\begin{tabular}{|c|c|c|c|c|}
\hline \multirow[t]{2}{*}{ Treatments } & \multicolumn{2}{|l|}{$\mathrm{K}(\%)$} & \multicolumn{2}{|l|}{$\mathrm{Ca}(\%)$} \\
\hline & Straw & Grain & Straw & Grain \\
\hline Control & $1.75 \pm 0.06 \mathrm{a}$ & $4.46 \pm 0.13 a b$ & $0.31 \pm 0.01 \mathrm{bc}$ & $0.35 \pm 0.01$ \\
\hline WS $\left(50 \mathrm{~g} \mathrm{~kg}^{-1}\right)$ & $1.55 \pm 0.11 b$ & $4.48 \pm 0.10 \mathrm{a}$ & $0.30 \pm 0.02 \mathbf{c}$ & $0.33 \pm 0.02$ \\
\hline A. magusensis & $1.45 \pm 0.02 \mathrm{~cd}$ & $4.47 \pm 0.06 \mathbf{a}$ & $0.41 \pm 0.01 \mathrm{a}$ & $0.33 \pm 0.01$ \\
\hline A. orientalis & $1.46 \pm 0.01 \mathrm{~cd}$ & $4.52 \pm 0.05 a$ & $0.42 \pm 0.01 \mathrm{a}$ & $0.37 \pm 0.01$ \\
\hline A. azurea & $1.47 \pm 0.02$ bc & $4.26 \pm 0.12 \mathbf{b}$ & $0.42 \pm 0.01 \mathrm{a}$ & $0.36 \pm 0.01$ \\
\hline A. magusensis $+50 \mathrm{~g} \mathrm{WS} \mathrm{kg}^{-1}$ & $1.37 \pm 0.02 \mathrm{de}$ & $3.52 \pm 0.12 \mathrm{c}$ & $0.32 \pm 0.01 b$ & $0.33 \pm 0.01$ \\
\hline A. orientalis $+\mathbf{5 0 g} \mathbf{~ W S ~} \mathbf{k g}^{-1}$ & $1.36 \pm 0.01 \mathbf{e}$ & $3.23 \pm 0.19 d$ & $0.32 \pm 0.01 \mathrm{~b}$ & $0.33 \pm 0.01$ \\
\hline 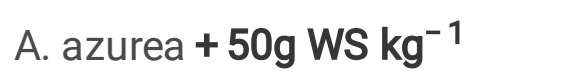 & $1.34 \pm 0.04 \mathbf{e}$ & $3.05 \pm 0.09 d$ & $0.32 \pm 0.01 \mathrm{~b}$ & $0.33 \pm 0.02$ \\
\hline F-value & $20.579 * \star \star$ & $86.854^{\star \star \star}$ & $107.357^{\star \star \star}$ & $3.887^{\mathrm{ns}}$ \\
\hline
\end{tabular}

\section{Soil microbiological properties}

As a result of the inoculation with Amycolatopsis strains alone and together with WS, and its effects on $\mathrm{C}_{\text {org }}$ and some microbiological properties are given in Table 4. It is determined that inoculating Amycolatopsis strains alone to soil and the change in $\mathrm{C}_{\text {org }}$ content is not statistically significant, but as a result of infusing Amycolatopsis strains with WS, the most increase in $\mathrm{C}_{\text {org }}$ content occurs $(P<0.001)$. Similarly, it was found that WS application added to the soil at the level of $5 \%$ significantly increased the $\mathrm{C}_{\text {org }}$ content $(P<0.001)$. This is a clear indication that there will be more increases in $\mathrm{C}_{\text {org }}$ content with microbial inoculation when there is an adequate source of organic matter in the soil. When compared to the control and application of WS only, the main reason for the increase in $\mathrm{C}_{\text {org }}$ content is related to the microbial excretions are more common in this environment and contributions of capillary roots to $\mathrm{C}_{\text {org }}$ content with an increase in root secretions of better growing plant roots contribute (Powlson et al., 2001; Pinton et al., 2007). However, obtained results are limited to the 124-day greenhouse trial. Without a doubt, organic compounds in the soil will be used as a $\mathrm{C}$ source by the growing microorganism population after the experiment, and $\mathrm{C}_{\text {org }}$ content will also decrease (Li et al., 2018). 
Table 4

The effects of inoculating Amycolatopsis strains alone and together with WS on $\mathrm{C}_{\text {org }}$ and soil microbiological properties

\begin{tabular}{|c|c|c|c|c|c|}
\hline Treatments & Corg & SBR & $\mathrm{C}_{\mathrm{mic}}$ & $\mathrm{C}_{\text {mid }} / \mathrm{C}_{\text {org }}$ & $q \mathrm{CO}_{2}$ \\
\hline Control & $\begin{array}{l}0.42 \pm \\
0.10 \mathrm{~d}\end{array}$ & $\begin{array}{l}13.04 \pm \\
1.64 \mathbf{e}\end{array}$ & $\begin{array}{l}121.37 \pm \\
5.28 f\end{array}$ & $\begin{array}{l}1.23 \pm \\
0.27 \mathrm{~b}\end{array}$ & $\begin{array}{l}2.58 \pm \\
0.36 \mathrm{c}\end{array}$ \\
\hline WS $\left(50 \mathrm{~g} \mathrm{~kg}^{-1}\right)$ & $\begin{array}{l}3.01 \pm \\
0.03 c\end{array}$ & $\begin{array}{l}22.22 \pm \\
0.27 \mathrm{~d}\end{array}$ & $\begin{array}{l}182.91 \pm \\
2.94 e^{-}\end{array}$ & $\begin{array}{l}0.25 \pm \\
0.01 \mathrm{c}\end{array}$ & $\begin{array}{l}2.92 \pm \\
0.04 c\end{array}$ \\
\hline A.magusensis & $\begin{array}{l}0.34 \pm \\
0.12 \mathbf{d}\end{array}$ & $\begin{array}{l}55.74 \pm \\
3.19 c\end{array}$ & $\begin{array}{l}230.03 \pm \\
9.46 d\end{array}$ & $\begin{array}{l}3.06 \pm \\
0.98 \mathbf{a}\end{array}$ & $\begin{array}{l}5.82 \pm \\
0.44 \mathrm{~b}\end{array}$ \\
\hline A.orientalis & $\begin{array}{l}0.31 \pm \\
0.05 \mathbf{d}\end{array}$ & $\begin{array}{l}57.74 \pm \\
0.66 c\end{array}$ & $\begin{array}{l}244.22 \pm \\
9.53 c\end{array}$ & $\begin{array}{l}3.31 \pm \\
0.36 \mathbf{a}\end{array}$ & $\begin{array}{l}5.67 \pm \\
0.27 \mathbf{b}\end{array}$ \\
\hline A.azurea & $\begin{array}{l}0.35 \pm \\
0.16 \mathbf{d}\end{array}$ & $\begin{array}{l}59.12 \pm \\
2.39 c\end{array}$ & $\begin{array}{l}247.22 \pm \\
11.30 c\end{array}$ & $\begin{array}{l}2.95 \pm \\
0.01 \mathrm{a}\end{array}$ & $\begin{array}{l}5.75 \pm \\
0.37 b\end{array}$ \\
\hline $\begin{array}{l}\text { A.magusensis }+50 \mathrm{~g} \text { WS } \\
\mathrm{kg}^{-1}\end{array}$ & $\begin{array}{l}3.66 \pm \\
0.16 \mathbf{a}\end{array}$ & $\begin{array}{l}75.73 \pm \\
2.39 b\end{array}$ & $\begin{array}{l}283.75 \pm \\
11.33 b\end{array}$ & $\begin{array}{l}0.32 \pm \\
0.01 \mathrm{c}\end{array}$ & $\begin{array}{l}6.41 \pm \\
0.37 \mathbf{a}\end{array}$ \\
\hline $\begin{array}{l}\text { A.orientalis }+50 \mathrm{~g} \mathrm{WS} \mathrm{kg}^{-} \\
1\end{array}$ & $\begin{array}{l}3.76 \pm \\
0.18 \mathrm{a}\end{array}$ & $\begin{array}{l}81.26 \pm \\
3.00 \mathbf{a}\end{array}$ & $\begin{array}{l}321.82 \pm \\
9.19 \mathbf{a}\end{array}$ & $\begin{array}{l}0.36 \pm \\
0.03 c\end{array}$ & $\begin{array}{l}6.06 \pm \\
0.20 \mathrm{ab}\end{array}$ \\
\hline 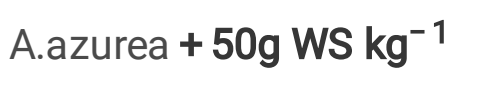 & $\begin{array}{l}3.29 \pm \\
0.07 \mathbf{b}\end{array}$ & $\begin{array}{l}80.14 \pm \\
4.14 \mathrm{ab}\end{array}$ & $\begin{array}{l}318.63 \pm \\
8.01 \mathrm{a}\end{array}$ & $\begin{array}{l}0.40 \pm \\
0.02 c\end{array}$ & $\begin{array}{l}6.04 \pm \\
0.44 a b\end{array}$ \\
\hline F-value & $702.180 * \star \star$ & $299.638^{\star \star *}$ & $221.191^{\star \star \star}$ & $28.778^{* \star \star}$ & $66.318^{\star \star \star}$ \\
\hline \multicolumn{6}{|l|}{$\star \star \star P<0.001$} \\
\hline \multicolumn{6}{|c|}{$\begin{array}{l}\mathrm{C}_{\text {org }} \text { : total organic carbon (\%); BSR: basal soil respiration }\left(\mathrm{mgCO}_{2}-\mathrm{C} \mathrm{gr}^{-1} .24 \mathrm{~h}\right) ; \mathrm{C}_{\text {mic }}: \text { microbial } \\
\text { biomass } \mathrm{C}\left(\mathrm{mg} \mathrm{C} \mathrm{g}^{-1} 24 \mathrm{~h}\right) ; \mathrm{C}_{\text {mic }} / \mathrm{C}_{\text {org }}: \% \text {; } q \mathrm{CO}_{2}: \text { the microbial metabolic quotient }\left(\mu \mathrm{g} \mathrm{CO}_{2}-\mathrm{C} \mathrm{mg}^{-1} \mathrm{C}_{\text {mic }}\right. \\
\left.\mathrm{h}^{-1}\right)\end{array}$} \\
\hline
\end{tabular}

Soil Basal Respiration (SBR) is defined as a constant respiration rate in the soil caused by the mineralization of organic matter, and it is estimated based on $\mathrm{CO}_{2}$ evolution or $\mathrm{O}_{2}$ uptake (Dilly and Zyakun, 2008). The determination of SBR measurement is a widely used indicator in the assessment of both microbial respiration in the soil and mineralization of organic matter (Creamer et al., 2014). In this study, the most SBR among applications was obtained by inoculation with Amycolatopsis strains with WS (Table 4). This is followed by inoculation with Amycolatopsis strains alone and WS, respectively $(P<0.001)$. This reveals that organic matter mineralization and microbial $\mathrm{CO}_{2}$ production in soils are mostly obtained in inoculation with Amycolatopsis strains. Similarly, studies carried out by Rui et al. (2016) and Mierzwa-Hersztek et al. (2018), it has been determined that SBR has significant increases by adding organic matter to the soil or by microbial inoculation. 
In this study, Substrate Induced Respiration (SIR) method was used to evaluate microbial biomass $\left(\mathrm{C}_{\mathrm{mic}}\right)$. Microbial population in soil produces $\mathrm{CO}_{2}$ from an easily degradable substrate in a simple structure added to soils. As a result of this, maximal respiration occurred at the beginning is determined, and this is widely used in $\mathrm{C}_{\text {mic }}$ estimation (Anderson and Domsch, 1978; Nakamoto and Wakahara, 2004). In this study, it was determined that all applications significantly increased $C_{\text {mic }}$ in soil $(P<0.001)$ when compared to the control application. Just like in SBR, the most $\mathrm{C}_{\text {mic }}$ is obtained in infusion with Amycolatopsis strains with WS. The obtained results show that microbial inoculation to soil and the addition of WS increases microbial biomass (Table 4). Similarly, with the studies carried out by Beare et al. (1990) and Rui et al. (2016), it has been determined that microbial inoculations and organic waste applications to soil significantly increases $\mathrm{C}_{\text {mic }}$. Besides, it is known that antibiotics synthesized by Amycolatopsis strains reduce populations by suppressing other microflora in the soil and rhizosphere region (Thomashow et al., 2008). Therefore, it can be said that Amycolatopsis strains inoculated with increased microbial activity in the experiment are dominant microorganisms in the soil environment.

The ratios of $\mathrm{C}_{\text {mic }}$ in $\mathrm{C}_{\text {org }}$ were calculated based on $\mathrm{C}_{\text {org }}$ and $\mathrm{C}_{\text {mic }}$ data of soils. According to the results obtained, the highest $\mathrm{C}_{\text {mic }} / \mathrm{C}_{\text {org }}$ ratios were obtained in applications where Amycolatopsis strains were inoculated (2.95-3.31). The lowest $\mathrm{C}_{\text {mic }} / \mathrm{C}_{\text {org }}$ rates were found in applications where WS and WS with Amycolatopsis strains were applied (Table 4). Although the ideal $\mathrm{C}_{\mathrm{mic}} / \mathrm{C}_{\text {org }}$ ratio varies between $1-4 \%$ in agricultural soils, the ideal rate is intended to be around $5 \%$, and the $\mathrm{C}_{\mathrm{mic}} / \mathrm{C}_{\text {org }}$ ratio alone provides a more sensitive assessment opportunity compared to the evaluation of $C_{\text {org }}$ and $C_{\text {mic }}$ alone (Sparling, 1992). This case reveals that the most appropriate application in terms of balance and approach to ideal conditions that will occur at the end of $\mathrm{C}_{\text {org }}$ and infusion in soils can only be obtained in applications where Amycolatopsis strains are inoculated.

The microbial metabolic quotient or $q \mathrm{CO}_{2}$ is a microbial respiration rate for one $\mathrm{C}_{\text {mic }}$ unit and it represents the capacity of microorganisms in the soil to use $\mathrm{C}_{\text {org }}$ (Chao et al., 2019). According to the results obtained from the study, the highest $q \mathrm{CO}_{2}$ values were obtained in applications where Amycolatopsis strains were inoculated with WS (6.04-6.41). This is followed by Amycolatopsis strains inoculations and WS application, respectively (Table 4). This case is a clear indication that the inoculation of Amycolatopsis strains in the soil also uses WS which is added to the soil. Because in these applications, not only $q \mathrm{CO}_{2}$ was determined high but also $\mathrm{C}_{\text {mic }}$ and SBR of the soils were found high (Table 3).

\section{Conclusions}

A combination of microorganisms and microbial fertilizer applications into the soil has comprehensive and multiple functions to promote sustainable agriculture and reducing environmental pollution and longterm adverse effects on soil fertility. However, not all types of microorganisms could serve for these purposes. Hence, it is essential to determine the microorganism species that can be used for such as microbial fertilizer purposes, the soil improving characteristics. Since microorganisms that can be used 
for microbial fertilizer are mostly heterotrophic, an increase in soil organic substance level will increase the effectiveness of these organisms and has more effect on plant crop yield. Besides, soil organic substance plays a critical role in these organisms to survive in the soil. In this study, it was determined that inoculation of A.magusensis DSM $45510^{\top}$, A.magusensis DSM $45510^{\top}$, and A.orientalis DSM $40040^{\top}$, from Amycolatopsis strains, significantly increased yield and nutrient content of the wheat. Although organic substances amendment increased the activity of these microorganisms, it was found that it significantly reduced the yield of plant crops. Contradictory, the greenhouse experiment proved that yield could be increased with Amycolatopsis strains inoculation, especially in soils without organic material input with insufficient soil organic substance located in the arid/semi-arid climate zones. However, it is necessary to expand the study results with field experiments by including different plant species. The next step will be microbial fertilizer production. The effect of microbial inoculation on plant growth should be assessed using the changes in soil microbial properties and yield parameters together.

\section{Declarations}

\section{Acknowledgment}

We are acknowledging TUBITAK-BIDEB 2216, Research Fellowship Programme for Foreign Citizens for postdoctoral fellowship Ref: B.14.2.TBT.0.06.01.03-216.01-136/6950.

\section{Ethics approval and consent to participate}

Not applicable

\section{Consent for publication}

Not applicable

\section{Availability of data and materials}

The datasets used and/or analysed during the current study are available from the corresponding author on reasonable request.

\section{Competing interests}

The authors declare that they have no competing interests.

\section{Funding}

This study was funded by TUBITAK-BIDEB 2216, Research Fellowship Program for Foreign Citizens for postdoctoral fellowship Ref: B.14.2.TBT.0.06.01.03-216.01-136/6950.

\section{Authors' contributions}


RK and MK conceived of the presented idea, verified the analytical methods. RK developed the field design and performed the computations, participated in the sequence alignment and drafted the manuscript. MK carried out the all field and laboratory experiments, supervised the findings of this work. All authors discussed the results and approved the final manuscript.

\section{References}

1. Ahmad M, Pataczek L, Hilger TH, Zahir ZA, Hussain A, Rasche F, Schafleitner R, Solberg S (2018) Perspectives of microbial inoculation for sustainable development and environmental management. Front Microbiol 9: 2992. https://dx.doi.org/10.3389\%2Ffmicb.2018.02992

2. Anderson JPE (1982) Soil respiration. In. Methods of soil analysis, Part 2- Chemical and Microbiological Properties, Page AL, Keeney DR, Baker DE, Miller RH, Ellis R Jr., Rhoades JD (eds). ASA-SSSA, Madison. pp 831-871

3. Anderson JPE, Domsch KH (1978) A physiological method for the quantitative measurement of microbial biomass in soils. Soil Biol Biochem 10(3):215-221. https://doi.org/10.1016/00380717(78)90099-8

4. Backer R, Rokem JS, Ilangumaran G, Lamont J, Praslickova D, Ricci E, Subramanian S, Smith DL (2018) Plant growth-promoting rhizobacteria: context, mechanisms of action, and roadmap to commercialization of biostimulants for sustainable agriculture. Front Plant Sci 9:1473. https://doi.org/10.3389/fpls.2018.01473

5. Banerjee MR, Yesmin L, Vessey JK (2005) Plant growth promoting rhizobacteria as biofertilizers and biopesticides. In: Rai MK (Ed.) In: Handbook of microbial biofertilizers. Food Product Press, New York, pp. $137-181$

6. Beare MH, Neely CL, Coleman DC, Hargrove WL (1990) A substrate-induced respiration (SIR) method for measurement of fungal and bacterial biomass on plant residues. Soil Biol Biochem 22(5):585594. https://doi.org/10.1016/0038-0717(90)90002-H

7. Bevivino A, Sarocco S, Dalmastri C, Tabacchino S, Cantale C, Chiarini L (1998) Characterization of a free-living maize-rhizosphere population of Burkholderia cepacia: Effect of seed treatment on disease suppression and growth promotion of maize. FEMS Microbiol Ecol 27(3):225-227. https://doi.org/10.1016/S0168-6496(98)00069-5

8. Brock C, Fließbach A, Oberholzer HR, Schulz F, Wiesinger K, Reinicke F, Koch W, Pallutt B, Dittman B, Zimmer J, Hülsbergen KJ, Leithold G (2011) Relation between soil organic matter and yield levels of nonlegume crops in organic and conventional farming systems. J Plant Nutr Soil Sci 174(4):568575. https://doi.org/10.1002/jpln.201000272

9. Cakmakci R, Kantar F, Sahin F (2001) Effect of $\mathrm{N}_{2}$-fixing bacterial inoculations on yield of sugar beet and barley. J Plant Nutr Soil Sci 164(5):527-531. https://doi.org/10.1002/15222624(200110)164:5\%3C527::AID-JPLN527\%3E3.0.C0;2-1

10. Cao Y, Xu L, Zhang Z, Chen Z, He N (2019) Soil microbial metabolic quotient in inner mongolian grasslands: patterns and influence factors. Chin Geogra Sci 29:1001-1010. 
https://doi.org/10.1007/s11769-019-1084-5

11. Creamer RE, Schulte RPO, Stone D, Gal A, Krogh PH, Lo Papa G, Murray PJ, Pérès G, Foerster B, Rutgers M, Winding A (2014) Measuring basal soil respiration across Europe: Do incubation temperature and incubation period matter? Ecol Ind 36:409-418.

https://doi.org/10.1016/j.ecolind.2013.08.015

12. Dilly O, Zyakun A (2008) Priming effect and respiratory quotient in a forest soil ammended with glucose. Geomicrobiol J 25:425-431. https://doi.org/10.1080/01490450802403099

13. Egamberdiyeva D (2005) Plant-growth-promoting rhizobacteria isolated from a Calcisol in a semiarid region of Uzbekistan: biochemical characterization and effectiveness. J Plant Nutr Soil Sci 168(1):94-99. https://doi.org/10.1002/jpln.200321283

14. Esitken A, Yildiz HE, Ercisli S, Donmez MF, Turan M, Gunes A (2010) Effects of plant growth promoting bacteria (PGPB) on yield, growth and nutrient contents of organically grown strawberry. Sci Hortic 124:62-66. http://dx.doi.org/10.1016/j.scienta.2009.12.012

15. Espe MB, Kirk E, van Kessel C, Horwath WH, Linquist BA (2015) Indigenous nitrogen supply of rice is predicted by soil organic carbon. Soil Sci Soc Am J 79(2):569-576. https://doi.org/10.2136/sssaj2014.08.0328

16. Fageria NK (2012) Role of soil organic matter in maintaining sustainability of cropping systems. Commun Soil Sci Plant Anal 43(16):2063-2113. DOl:http://dx.doi.org/10.1080/00103624.2012.697234

17. FAO (2015) World reference base for soil resources 2014. International soil classification system for naming soils and creating legends for soil maps. Update 2015. World Soil Resources Report No. 106. Food and Agriculture Organization of the United Nations (FAO), Rome, Italy. http://www.fao.org/3/ai3794en.pdf

18. Fleige C, Meyer F, Steinbüchel A (2016) Metabolic Engineering of the Actinomycete Amycolatopsis sp. strain ATCC 39116 towards Enhanced Production of Natural Vanillin. Appl Environ Microbiol 82(11):3410-3419. https://doi.org/10.1128/AEM.00802-16

19. Fleige C, Steinbüchel A (2014) Construction of expression vectors for metabolic engineering of the vanillin-producing actinomycete Amycolatopsis sp. ATCC 39116. Appl Microbiol Biotechnol 98:6387-6395. https://doi.org/10.1007/s00253-014-5724-5

20. Frasch HJ, Kalan L, Kilian R, Martin T, Wright GD, Stegmann E (2015) Alternative pathway to a glycopeptide-resistant cell wall in the balhimycin producer Amycolatopsis balhimycina. ACS Infectious Diseases 1(6):243-252. https://doi.org/10.1021/acsinfecdis.5b00011

21. Garcia de Salamone IE, Hynes RK, Nelson LM (2001) Cytokinin production by plant growth promoting rhizobacteria and selected mutants. Can J Microbiol 47(5):404-411. https://doi.org/10.1139/w01029

22. Gouda S, Kerry RG, Das G, Paramithiotis S, Shin HS, Patra JK, Revitalization of plant growth promoting rhizobacteria for sustainable development in agriculture. Microbiological Research 206: 131-140. https://doi.org/10.1016/j.micres.2017.08.016 
23. Gutiérrez-Mañero FJ, Ramos-Solano B, Probanza A, Mehouachi J, Tadeo FR, Talon M (2001) The plant-growth-promoting rhizobacteria Bacillus pumilus and Bacillus licheniformis produce high amounts of physiologically active gibberellins. Physiol Plant 111(2):206-211. https://doi.org/10.1034/j.1399-3054.2001.1110211.x

24. Hussain T, Javaid T, Parr JF, Jilanoi G, Haq MA (1999) Rice and wheat production in Pakistan with effective microorganisms. Am J Altern Agric 14:30-36.

https://doi.org/10.1017/S0889189300007980

25. Jones JB (2001) Laboratory guide for conducting soil tests and plant analyses. CRC Press, New York, $363 p$

26. Jones JB Jr, Wolf B, Mills HA (1991) Plant Analysis Handbook: A Practical Sampling, Preparation, Analysis, and Interpretation Guide. Micro-Macro Publishing, Athens

27. Kızılkaya R (2008) Yield response and nitrogen concentrations of spring wheat (Triticum aestivum) inoculated with Azotobacter chroococcum strains. Ecol Eng 33(2):150-156.

http://dx.doi.org/10.1016/j.ecoleng.2008.02.011

28. Kızılkaya R (2009) Nitrogen fixation capacity of Azotobacter spp. strains isolated from soils in different ecosystems and relationship between them and the microbiological properties of soils. $J$ Environ Biol 30(1):73-82

29. Kumari R, Singh P, Lal R (2016) Genetics and genomics of the genus Amycolatopsis. Indian Journal of Microbiology 56(3):233-246. https://doi.org/10.1007/s12088-016-0590-8

30. Li J, Wu X, Gebremikael MT, Wu H, Cai D, Wang B, Li B, Zhang J, Li Y, Xi J (2018) Response of soil organic carbon fractions, microbial community composition and carbon mineralization to high-input fertilizer practices under an intensive agricultural system. PLOS One 13(4): e0195144. https://dx.doi.org/10.1371\%2Fjournal.pone.0195144

31. Lucy M, Reed E, Glick BR (2004) Applications of free living plant growth-promoting rhizobacteria. Antonie Van Leeuwenhoek 86(1):1-25. https://doi.org/10.1023/B:ANT0.0000024903.10757.6e

32. Mierzwa-Hersztek M, Klimkowicz-Pawlas A, Gondek K (2018) Influence of Poultry Litter and Poultry Litter Biochar on Soil Microbial Respiration and Nitrifying Bacteria Activity. Waste and Biomass Valorization 9: 379-389 (2018). https://doi.org/10.1007/s12649-017-0013-z

33. Murphy BW (2015) Impact of soil organic matter on soil properties-a review with emphasis on Australian soils. Soil Research 53(6):605-635. https://doi.org/10.1071/SR14246

34. Nakamoto T, Wakahara S (2004) Development of Substrate Induced Respiration (SIR) Method Combined with Selective Inhibition for Estimating Fungal and Bacterial Biomass in Humic Andosols. Plant Production Science 7(1):70-76. https://doi.org/10.1626/pps.7.70

35. Nigam A, Almabruk KH, Saxena A, Yang J, Mukherjee U, Kaur H, Kohli P, Kumari R, Singh P, Zakharov LN, Singh Y, Mahmud T, Lal R (2014) Modification of rifamycin polyketide backbone leads to improved drug activity against rifampicin-resistant Mycobacterium tuberculosis. J Biol Chem 289:21142-21152. https://doi.org/10.1074/jbc.M114.572636 
36. Ogut M, Er F (2016) Mineral composition of field grown winter wheat inoculated with phosphorus solubilizing bacteria at different plant growth stages. J Plant Nutr 39(4):479-490. https://doi.org/10.1080/01904167.2015.1047518

37. Orhan E, Esitken A, Ercisli S, Turan M, Sahin F (2006) Effects of plant growth promoting rhizobacteria (PGPR) on yield, growth and nutrient contents in organically growing raspberry. Sci Hortic 111(1):3843. https://doi.org/10.1016/j.scienta.2006.09.002

38. Ortega-González DK, Martínez-González G, Flores CM, Zaragoza D, Cancino-Diaz JC, Cruz-Maya JA, Jan-Roblero J (2015) Amycolatopsis sp. Poz14 isolated from oil-contaminated soil degrades polycyclic aromatic hydrocarbons. International Biodeterioration \& Biodegradation 99: 650-173. https://doi.org/10.1016/j.ibiod.2015.01.008

39. Pinton R, Varanini Z, Nannipieri P (2007) The Rhizosphere. Biochemistry and Organic Substances at the Soil Plant Interface. Second Edition. CRC Press, Boca Raton, USA. 447p

40. Powlson DS, Hirsch PR, Brookes PC (2001) The role of soil microorganisms in soil organic matter conservation in the tropics. Nutr Cycl Agroecosyst 61:41-51.

https://doi.org/10.1023/A:1013338028454

41. Rowell DL (1996) Soil Science: methods an applications. Longman, UK

42. Rui Y, Murphy D, Wang X, Hoyle FC (2016) Microbial respiration, but not biomass, responded linearly to increasing light fraction organic matter input: Consequences for carbon sequestration. Sci Rep 6:35496. https://doi.org/10.1038/srep35496

43. Saubidet MI, Fatta N, Barneix AJ (2002) The effect of inoculation with Azospirillum brasilense on growth and nitrogen utilization by wheat plants. Plant Soil 245:215-222.

https://doi.org/10.1023/A:1020469603941

44. Sparling GP (1992) Ratio of microbial biomass carbon to soil organic carbon as a sensitive indicator of changes in soil organic matter. Aust J Soil Res 30(2):195-207. https://doi.org/10.1071/SR9920195

45. Tan GYA, Ward AC, Goodfellow M (2006) Exploration of Amycolatopsis diversity in soil using genusspecific primers and novel selective media. Syst Appl Microbiol 29(7):557-569. https://doi.org/10.1016/j.syapm.2006.01.007

46. Thomashow LS, Bonsall RF, Weller DM, 2008, Detection of Antibiotics Produced by Soil and Rhizosphere Microbes In Situ. In: Secondary Metabolites in Soil Ecology. Karlovsky P. (eds) Soil Biology, vol 14. pp 23-36. Springer, Berlin, Heidelberg https://doi.org/10.1007/978-3-540-74543-3_2

47. Valarini PJ, Díaz Alvarez MC, Gascó JM, Guerrero F, Tokeshi H (2003) Assessment of soil properties by organic matter and EM-microorganism incorporation. Revista Brasileira de Ciência do Solo 27(3):519-525. https://doi.org/10.1590/S0100-06832003000300013

48. Xu L, Huang H, Wei W, Zhong Y, Tang B, Yuan H, Zhu L, Huang W, Ge M, Yang S, Zheng H, Jiang W, Chen D, Zhao GP, Zhao W (2014) Complete genome sequence and comparative analyses of the vancomycin-producing Amycolatopsis orientalis. BMC Genom 15:363. https://doi.org/10.1186/14712164-15-363 
49. Yadav J, Verma JP, Tiwari KN (2011) Plant growth promoting activities of fungi and their effect on chickpea plant growth. Asian Journal of Biological Sciences 4:291-299. http://dx.doi.org/10.3923/ajbs.2011.291.299

50. Zhao YN, He XH, Huang XC, Zhang YQ, Shi XJ (2016) Increasing soil organic matter enhances inherent soil productivity while offsetting fertilization effect under a rice cropping system. Sustainability 8(9):879. https://doi.org/10.3390/su8090879 